\title{
尿中核酸量による腎炎の新診斷法
}

\author{
名古叚大学医学部生化学教室 \\ 沼信要, 田亭, 石川籍治
}

\section{A NEW DIAGNOSTIC METHOD OF NEPHRITIS BY THE NUCLEIC ACID QUANTITY IN THE URINE}

By

Nobuhiko Katsunuma, Tôru Schòda. Eiji Isikawa,

(Department of Biochemistry, School of Medicine,

Nagoya university.)

We could first discover that nephritis patients excreted a large amount of nucleic iacid in their urine. By a modified Hammarsten method, we extracted the nucleic acid from the nephritis urine, which was identifiad by the following characterizations: the maximum absorption at $260 \mathrm{mu}$, the minimum at $230 \mathrm{mu}$, phosphate content $8.7 \%$, RNA/DNA ratio 1.6, diphenylamine and orcine reaction positive, and such five bases released on hydrolysis as adenine, guanine, cytosine, thymine and uracil. We detamined colorimetlycaly this urine nucleic acid amount by the use of diphenylamine reaction in the modified Schneider fraction. This nucleic acid appears to be derived from the destroyed renal cells, which was demonstrated to be connected closely with proteine, cylinders and renal epithelium excreted into the nephritis urine. Nucleic acid was not excreted in the urine of a healthy person, nor in the urine of cystitis and urethritis. The excretion of nucleic acid is specific to nephritis and in-creases in proportion to the disease. 


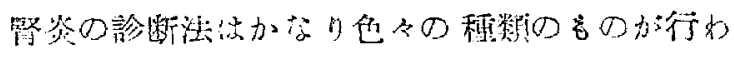
れている、機能检盉の重姴なこと情うまでもな

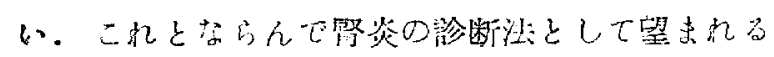

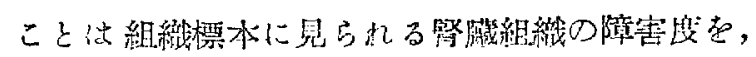

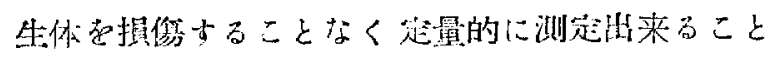

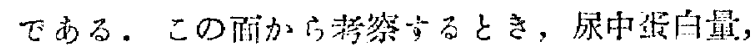

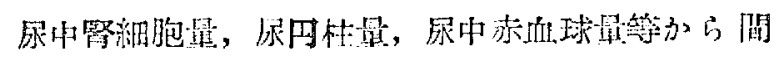

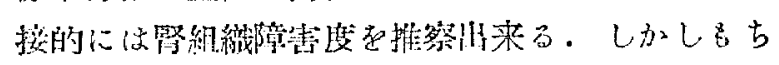

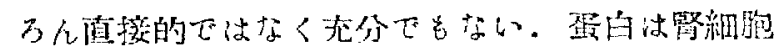

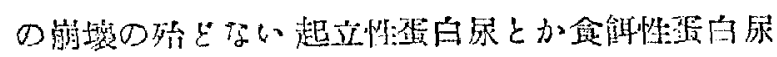
とかの機能的なものにも出現するし，急性期の等 炎よりる慢性期に多く出現したりする。るこでこ の日的を洼するに法等細胞由来の物筫を特異的に 层中から捕捉定量することであると考元た。先主

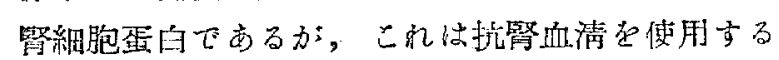
ことにより尿中汃ら或程度特異的に捕提出实るこ

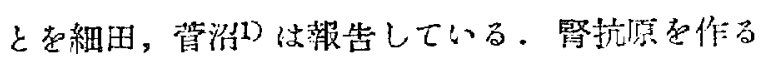
時に血清蛋白の混入をるけることふ心出来ないた め，原中血清由来の蛋白と多少性降反応を与 るが，市る程玲，腎細胞由来の蛋白量を推定出来

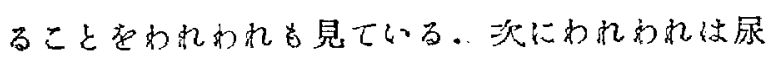
中から核酸の梌出を試みた。こ肌細胞付にのみ 存在し，腎櫒は高分子のま了では通過せま，体細

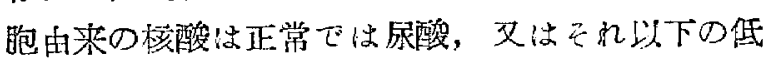
分子化合物として排出されることかわかつている からで亩る。こ、でわれわれ性 Miescher が初め て核酸を発見したのが，白血球の崩㙲產物であ る媳汃ら抽出したのに始まることを思い起こし た.

その結果，腎炎尿にのみ非常に多量の核酸办出 ていること知つたのである。腎炎尿中に核酸 (恐らく核蛋白の型で) が出ていること故見し た最初の報告であるけめに，このるのが核酸に問 遙いないことの証明には，特に注意を屾らつた。 徒つてこの腎炎尿中に出ている核酸は, 緊細胞 崩壞に由来すると考えるの汃自然であり，この様

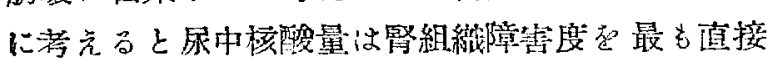

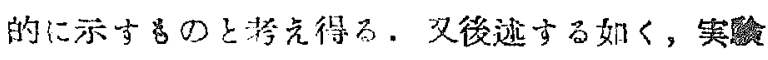

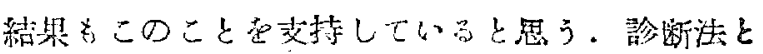

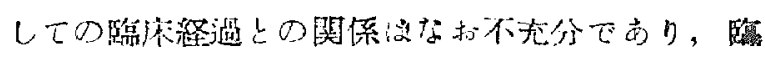
床榙家り御批制定得にく思つている。

\section{（1）定量法原びその䬶骶}

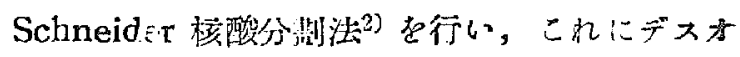
キシリボ核酸 (DNA)，及びリポ核酸 (RNA) の

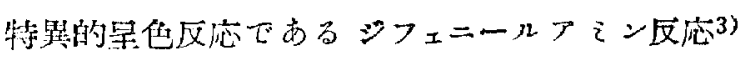

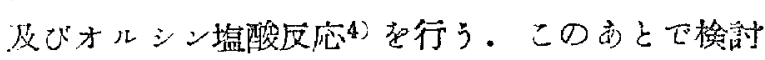

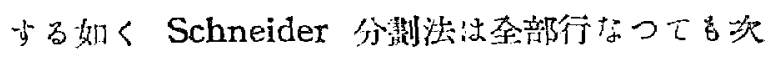
の如く簡易化したものでも，この場合に惒変りが ないために Table 1 の如き方㳙によることにし た。核酸分劃 $1.5 \mathrm{ml}$ にシフェニールアにン試薬

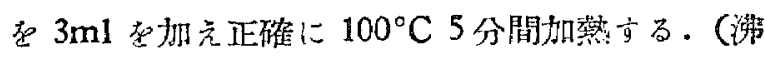

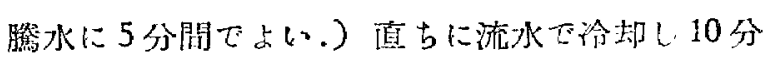

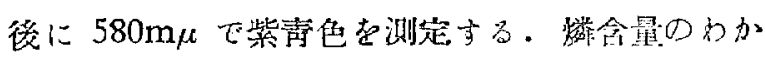
つた DNA で棒準直楾を作り，この DNA の

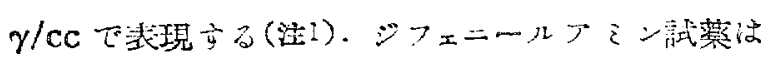
$40 \mathrm{cc}$ の水醋酸に $1.1 \mathrm{cc}$ の㴧硫酸支加克たものに $1 \%$ にる如くシフェニールフをン溶解す る(注2). (RNAで定量する場合蚛上清 $2 \mathrm{cc}$ に方儿 シン試菜在 $2 \mathrm{cc}$ 加え $100^{\circ} \mathrm{C} 20$ 分加熱し，直ちに 蒸溜水で2 倍に稀釈して 10 分啳に $620 \mathrm{~m} \mu$ で綠色 尼测定する。この場合虫重应例では RNAが多過

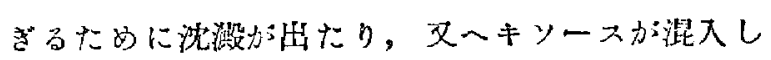
て褐色になる例怙あるので DNA 定量する方が 実用的に崔利である。) 次にこの定量法の検討

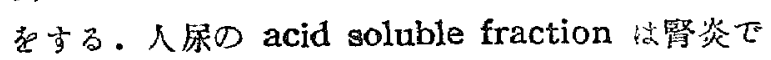
市るとないとに拘らす diphenylamine 反応で極

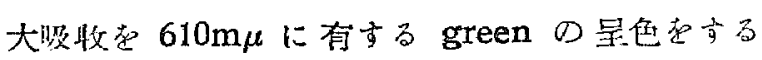
(本来の DNAによるちの㗪青色)，この物質 の本態は不明であるか：酸溶性で明かに核酸系化合 物ではない。しかる表2の如く5\%トリタロール 醋酸（TCA）で 3 回洗う焉により全くなくなる。 従つて前首つて2回 $5 \%$ TCA で洗觉ばこの物筫

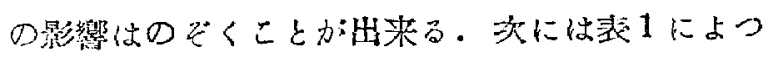
て得られた核酸フラカションは明かに $260 \mathrm{~m} \mu$ の

注 1. $\mathrm{E}=0.19$ は橉合量 $8.4 \%$ DNA200 $/ \mathrm{cc}-\mathrm{c}$ に相当する。

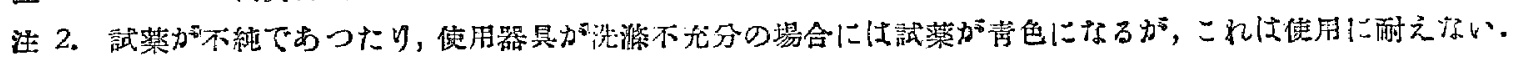


權大吸收を持つし，更に挠章に迅べる如くこの大 部分か確か:核酸であることを純粹の核酸を抽出 しこの性質るしらべることにより確かめた。にこの フラクションにオルシン塩酸反応を行う時，とき どき污裀色を星する。

また時には sialic acid のバーブルの呈色を することも市る所から，この分判には sialic acid その他の多糖体を含むことかしばしばあるのて， RNA の定量を行うのは不利である。)またその 中で Sialic acid : diphenylamine 反応か: DNA によるものと同色を星立るた幼，Table 1 の分 劃に diphenylamine 反応を行なつた場合は，時 には一部 sialic acidに上る呈色走含めた值と考 えるべきである。

Table 1.

Quantitative fractionation of nucleic acid $5 \mathrm{ml}$ of filtrated urine mixed with $5 \mathrm{ml}$ of $10 \% \mathrm{TCA}$ centrifuge
Sup. mixed with $5 \mathrm{ml}$ of $5 \%$ TCA centrifuge $\begin{array}{cc}1 & 1 \\ \text { Sup. } & \text { ppt. }\end{array}$ mixed with $5 \mathrm{ml}$ of $5 \%$ TCA heat at $90^{\circ} \mathrm{C}$, for 15 minutes centrifuge

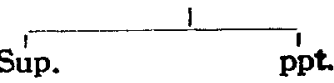

nucleic acid fraction

Table 2.

Deminution of diphenylamine positive substance in the acid soluble fraction ( $5 \%$ cold TCA fraction).

\begin{tabular}{|c|c|c|c|c|}
\hline $\begin{array}{l}\text { the num } \\
\text { wash } \\
\text { example }\end{array}$ & $\begin{array}{l}\text { ber of } \\
\text { ing times }\end{array}$ & once & twice & $\begin{array}{l}\text { three } \\
\text { times }\end{array}$ \\
\hline nephritis & No. 1 & 0.23 & 0.055 & 0 \\
\hline nephritis & No. 2 & 0.13 & 0.02 & 0 \\
\hline normal & No. 1 & 0.41 & 0.013 & 0 \\
\hline normal & No. 2 & 0.74 & 0.02 & 0 \\
\hline
\end{tabular}

\section{（2）病狀との相関}

本反応心健康者に性全然出ない，留炎及び混合 腎炎のみ强くなる。下部尿路疾患でも茎例出な い，蛋白は出ていても起立性蛋白尿等の機能性蛋 白尿には出ない。

（a）篎炎尿につき蛋白量との関係 蛋白量は末吉法によつた。

$$
\text { Table } 3 .
$$

Correlation between DNA quantity in nephritis urine and urine-proteine quantity.

\begin{tabular}{|c|c|c|c|c|}
\hline $\begin{array}{l}\text { protein } \\
\text { DNA } \\
r / c c\end{array}$ & $0 \sim$ & $2 \sim 4$ & $4 \sim 6$ & $6 \sim 10$ \\
\hline $0 \sim 50$ & 6 & 0 & 0 & 0 \\
\hline $50 \sim 100$ & 0 & 2 & 0 & 1 \\
\hline $100 \sim 150$ & 0 & 2 & 2 & 0 \\
\hline $150 \sim 200$ & 0 & 0 & 2 & 0 \\
\hline $200 \sim 300$ & 0 & 0 & 0 & 3 \\
\hline
\end{tabular}

(b) 督上皮及びZylinder との関係

表 4 に示す如き相関がある。

Table 4.

Correlation between DNA quantity in nephritis urine and both renal-epithel and renal-cylinder.

\begin{tabular}{|c|c|c|c|c|c|c|}
\hline \multirow[b]{2}{*}{$\begin{array}{l}\text { DNA } \\
\quad r / c c \backslash\end{array}$} & \multicolumn{3}{|c|}{ renal-epithel } & \multicolumn{3}{|c|}{ renal-cylinder } \\
\hline & + & $H$ & W & - & + & $H$ \\
\hline $0 \sim 50$ & 6 & 1 & 0 & 5 & 4 & 0 \\
\hline $50 \sim 100$ & 0 & 1 & 0 & 1 & 0 & 0 \\
\hline $100 \sim 150$ & 0 & 3 & 1 & 2 & 2 & 1 \\
\hline $150 \sim 300$ & 0 & 3 & 2 & 0 & 2 & 2 \\
\hline
\end{tabular}

(c) 経過との関係

3，4例しか行なつてないが，急性期に核酸反応 が强いものは予後が悪いようである．堅組織の崩 懐度か强いからで性あるまいか，ある所から急上 昇したもので㱜亡した者がある。治療する時は蛋 白より早目に核酸反応は減少する様である。この 
面では例が少なく今後の研究により明かにした Q.

(d) 核酸反応の疾患特異性

健康人 12名につき全例除性であつた。起立性蛋 白尿 2 名で陰性，下部尿路疾患, Urethritis 4 名， Cystitis 2 名て陰性, Epididymitis tuberculos 2 名, 白血病 2 名, ボリオ 尿症 1 名で陰性であつた，従つて简炎，混合惄炎 以外の疾患に峙然出ない事か明かである，但し 非常に重要な事であるが，ネフローゼ尿が入手出 来なかつたためこれについて虫不明である。

\section{（3） 本校酸の由来（出現撒轉）}

本物質が督臟の細胞に由来するものであれば， 督炎尿中の腎細胞蛋白と一定の関係がある筈であ る。るこで蒙患を使用して抗人留血清を作り，こ れと腎炎尿との間に沈淑反応老行なった所，細 田，菅沼も見ている上万に重症腎炎尿は强い沈降

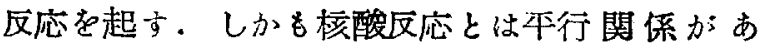
る. ( 2 倍尿迄陽性のすの核酸反応 $16 \gamma / \mathrm{cc}, 16$ 倍尿迄のもの方 $57 \mathrm{r} / \mathrm{cc}, 64$ 倍尿迄の8のか; $168 \mathrm{r} / \mathrm{cc} ， 128$ 倍尿迄の 6 の $98 \mathrm{r} / \mathrm{cc}$ ，健康人尿 2 例で両反応共 0 であつた．抗人緊血清は抗血清 を混合しているので正確を期しがたいが，ほゔ腎 臟細胞由来の蛋白量と本行関係があると見る重が 出来る，次に血清由来が如何かを見るために婜炎 及び健康者の血清中の本反応値をしらへだか，尿 核酸には著明な変動があるにも拘らす，血清核酸 には変動か殆となく，而も極めて少量しか血清中 には存在しない事加らも血清由来の核酸とは考え にくい事を知つだ。この二つの実験 と，腎細胞の 崩堎の㱠どないと思われる機能性蛋白尿に沖出現 しない現象と老併せ考党ると，この核酸は简細盷 の崩壤に由来するるのと考劣ることが出来よう。

\section{（4）柾戝てあることの確認}

腎炎尿に出ている Schneider 分劃シフェニール フミン陽性物質の大部分が核酸であることを次の 如く多量の腎炎㽷から栖酸を抽出し，その性状支 しらべ，五つの base 確認することにより決定 した。方法は表 5 の如し。
Table 5

Extraction method of nephritis urine nucleic acid

nephritis urine ( $\left.\begin{array}{ll}2 & 1\end{array}\right)$ add 50\% TCA to 50\% finalconcentration

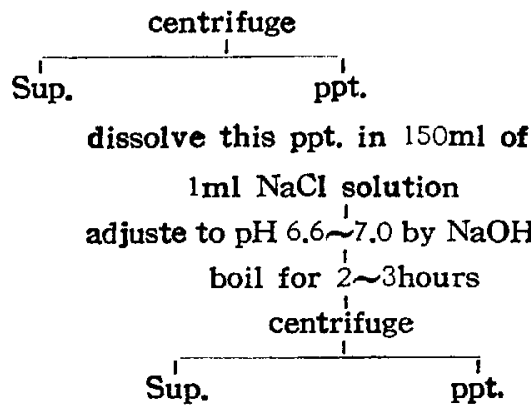

add 4 fold volumes

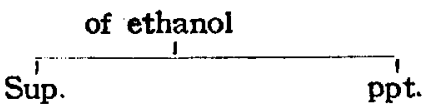
dissolve this ppt. in $70 \mathrm{ml}$. of $1 \mathrm{~mol} \mathrm{NaCl}$ solution centrifuge

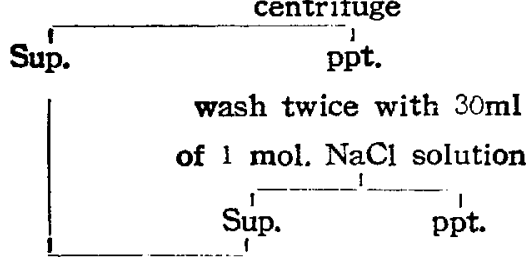

deproteinize by Sevag's

chloroform method, for 24 hours

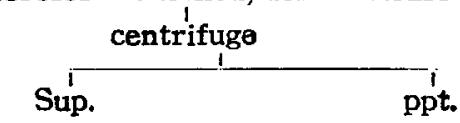

add 4 fold volumes

of ethanol

centrifuge

Sup. ppt.

dissolve this ppt in $50 \mathrm{ml}$ of $1 \mathrm{ml} \mathrm{NaCl}$ solution deproteinize by Sevag's method for $5 \sim 7$ days

(until the membrane of boundary disappears)

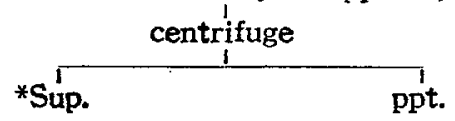

日本冈科学会雑誈 第44卷 第12号 


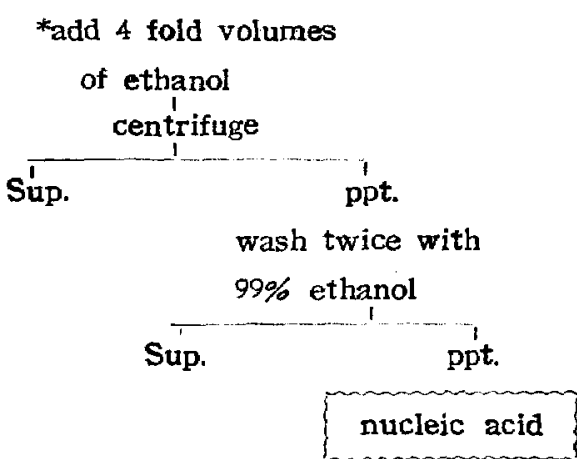

Table 6.

Nature of this nephritis urine nucleic acid maximum absorption $258 \mathrm{~m} \mu$ minimum absorption $230 \mathrm{~m} \mu$ phosphate content $8.7 \%$ RNA : DNA ratio 60\%: $40 \%$ adenine, guanine base composition cytosine, thymine, diphenylamine reaction violet-blue orcine- $\mathrm{HCl}$ reaction green

この方法で腎炎尿 $2 l$ 中から燐会量 $8.7 \%$ の核 酸か; 30 40mg 得られる.この核酸仙 DNA RNA の混合物で，オルシン反応は全尿の時を異 なり美しいgreenの星色をする故 RNAである。 多糖体治㱠ど含まない.シフェニールフシン反応と オルシン反忘から RNA/DNA $=1.6$ の比に混合 している。この值は普通の細跑に於ける RNA/D NA の含有比に略々一致する。次にこの核酸を $5 \mathrm{~N}$ 熄酸で 24 時間 $100^{\circ} \mathrm{C}$ で水解する。これを $2 \mathrm{~N}$ 㙁酸ープロパノール系 $(35: 65)$ て PPCに上り展開 士る5。各 base そネラルライトで見ると Rf. 0.34 guanine, 0.47 adenine, 0.54 cytosine, 0.74 uracil, 0.87 thymine $と$ 五つの base t確

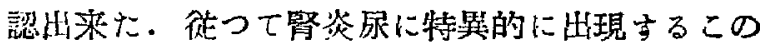
物質が DNA \& RNA の湿合した核酸である事 在確認した。この吸收䌽図 1 の如く $260 \mathrm{~m} \mu$ に極 大吸收有する核酸特有のるのである. 30 年 4 月 內科学会の報告では未げ蛋白多く念む未精製の もの少最しか得ていない段階てあった為めに

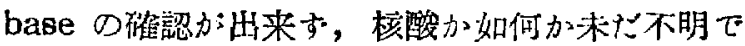
あると報告したが，こるでデーターによりこのよ うに訂正する。

\section{結 喰}

われわれは㹂炎尿中にのみ Schneider 分 劃 シ フェニールナえン陽性物質が出現すること在初め て報告した。炏いで腎炎沓加核酸を抽出し，飞 の性質をしらべ水解によりブリンとビリミジ

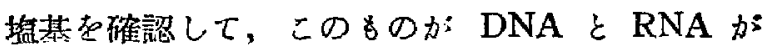
$40 \%$ \% $60 \%$ の比に混合した核酸である事を確証 すると同時に祭炎尿中の核酸の由来及び性質き明

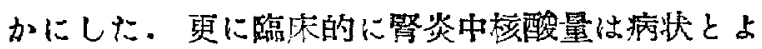

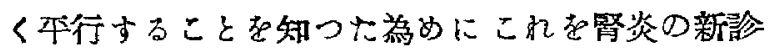
断法に使用出来ることを報告した。

にの一部は昭和30年 4 月 5 日日本內科学会䅂会て 生表した.)

\section{女献}

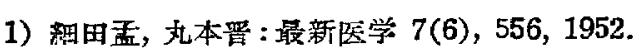

2) W. C. Schneider : J. Biol. Chem. 161, 293, 1945.

3) Z. Dische: Mikrochemie : 2, 26, 1930.

4) S. E. Kerr, R. H. Seraidarian : J. Biol. Chem. 159, 211, 1945.

5) 谷 淳吉, 寺井武雄, 山村好弘：綰核生化学談話 昭和30年 3 月

【受稿・昭和30年10月13日] 